\title{
Correction to: Aerodynamics and dynamic stability of micro-air-vehicle with four flapping wings in hovering flight
}

Cheng Cheng ${ }^{1}$, Jianghao $\mathrm{Wu}^{1}$, Yanlai Zhang ${ }^{1}$, Han $\mathrm{Li}^{2}$ and Chao Zhou ${ }^{1 *}$

The original article can be found online at https://doi.org/10.1186/ s42774-020-0029-0.

* Correspondence: zcqh821@163. com

${ }^{1}$ School of Transportation Science and Engineering, Beihang University, Beijing 100191, China Full list of author information is available at the end of the article
Correction to: Adv Aerodyn (2020) 2:5

https://doi.org/10.1186/s42774-020-0029-0

Following publication of the original article [1], the authors identified errors in Figs. 2 and 7. The correct figures are given below.

\section{Author details}

'School of Transportation Science and Engineering, Beihang University, Beijing 100191, China. ${ }^{2}$ The first Aircraft Design Institute, Aviation Industry Coorporation of China, Xi'an 710089, China.

Published online: 28 June 2020

\section{Reference}

1. Cheng C, Wu J, Zhang Y et al (2020) Aerodynamics and dynamic stability of micro-air-vehicle with four flapping wings in hovering flight. Adv Aerodyn 2:5 https://doi.org/10.1186/s42774-020-0029-0 original author(s) and the source, provide a link to the Creative Commons licence, and indicate if changes were made. The images or other third party material in this article are included in the article's Creative Commons licence, unless indicated otherwise in a credit line to the material. If material is not included in the article's Creative Commons licence and your intended use is not permitted by statutory regulation or exceeds the permitted use, you will need to obtain permission directly from the copyright holder. To view a copy of this licence, visit http://creativecommons.org/licenses/by/4.0/. 
(a)

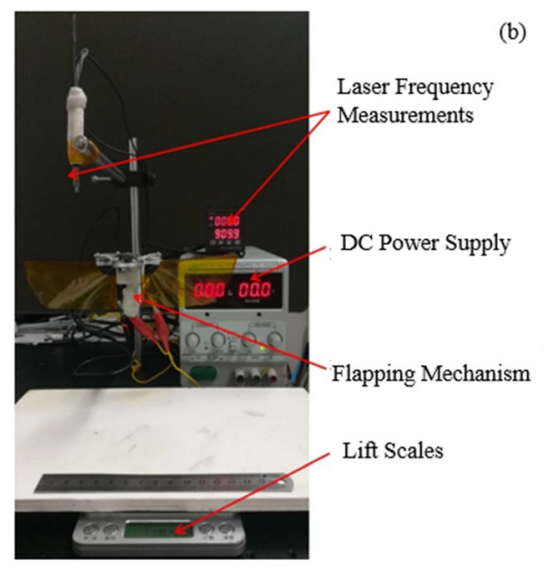

(b)

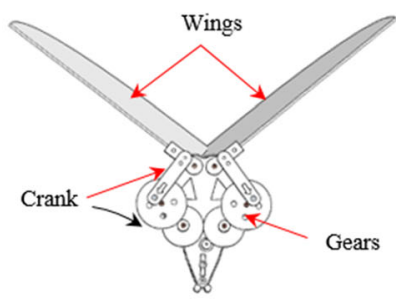

(c)

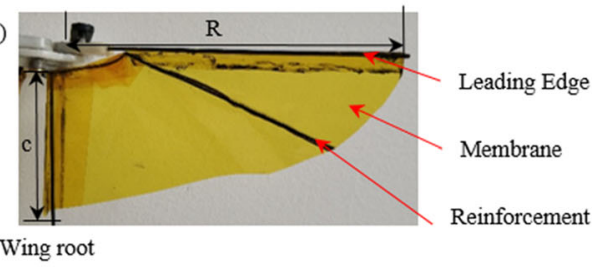

(d)

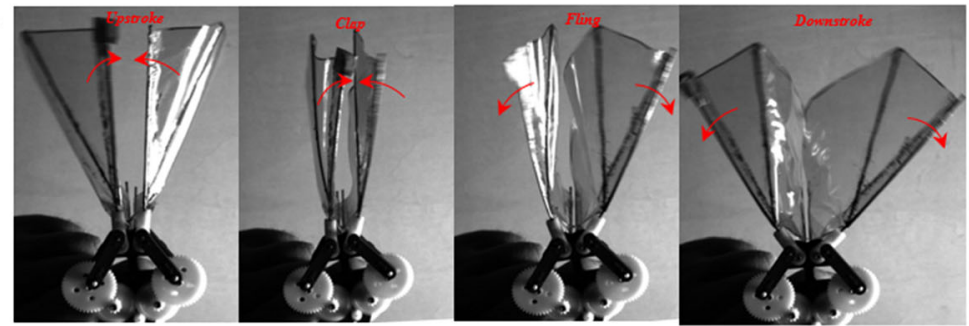

Fig. 2 Experimental apparatus and model (a) the fast lift measurement platform, (b) experimental test model, (c) Wing structure, (d) the flapping wings with clap-and-fling motion 


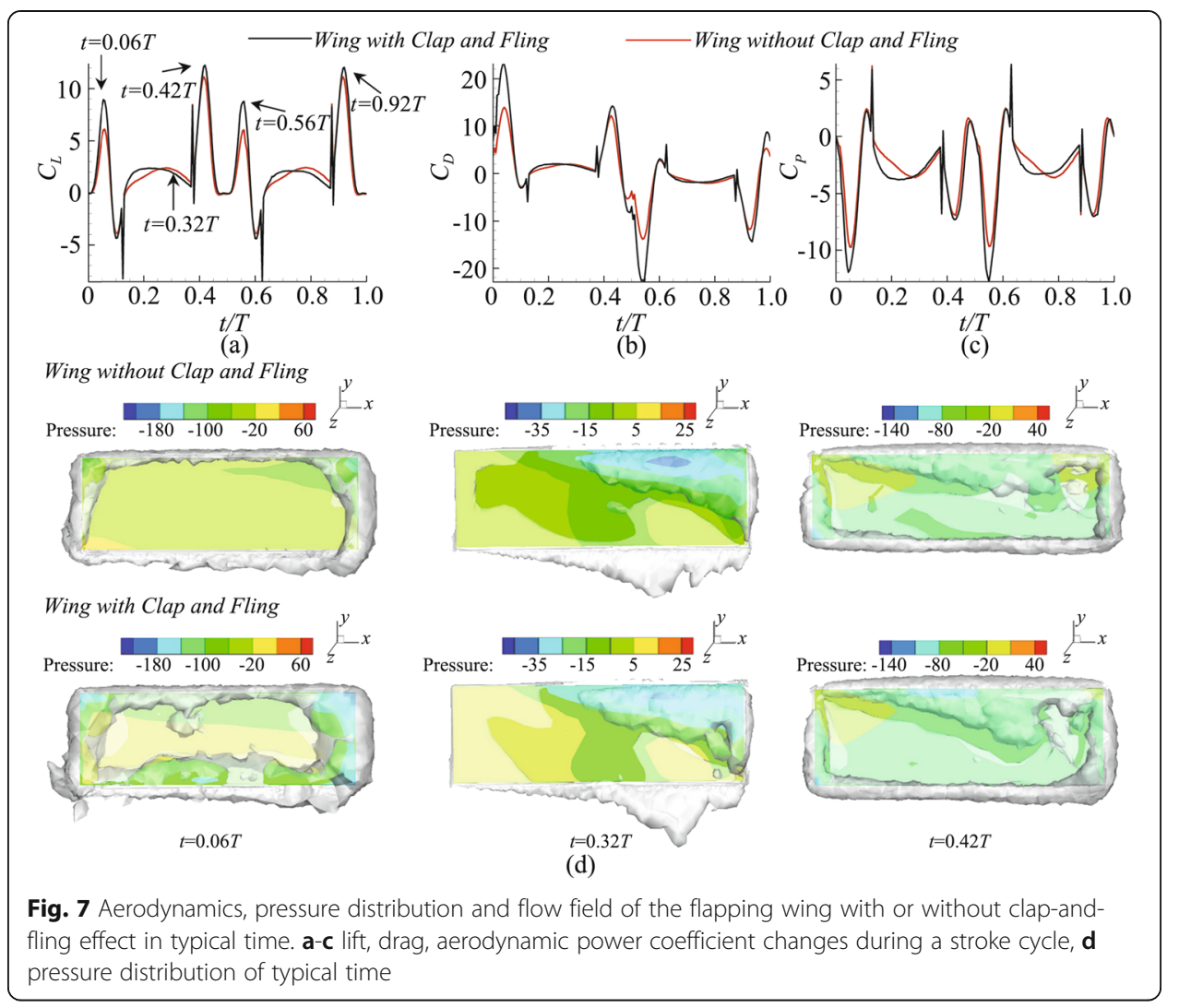

